\title{
Characterization of goat milk and potentially symbiotic non-fat yogurt
}

\author{
Noelia Fernanda PAZ ${ }^{1}$, Enzo Gonçalvez de OLIVEIRA ${ }^{1}$, \\ Martha Susana Nuñez de KAIRUZ ${ }^{2}$, Adriana Noemí RAMÓN ${ }^{1 *}$
}

\begin{abstract}
Combining prebiotics and probiotic microorganisms improve quality in the formulation of foods. In this paper, the characteristics of goat milk and symbiotic yogurt were studied. Raw goat milk was analyzed and the skimming process was optimized. For the formulation of a potentially non-fat symbiotic yogurt made with skimmed goat milk, inulin, gelatin, sugar, and Streptococcus salivarius subsp. thermophilus, Lactobacillus delbrueckii subsp. bulgaricus and Lactobacillus casei subsp. rhamnoshus. Chemical characteristics, acceptability, and viability of lactic acid bacteria and probiotic culture were assessed. The protein and fat content of the raw milk was 2.90 and $3.56 \mathrm{~g} / 100 \mathrm{~mL}$, respectively. The optimum skimming process was obtained at 9,800 rpm and 4 ${ }^{\circ} \mathrm{C}$ for 15 minutes. The product formulated had a protein and fat content of 4.04 to $0.04 \mathrm{~g} / 100 \mathrm{~mL}$, good sensory properties, and acceptability of $95 \%$. The lactic bacteria count was $9 \times 10^{7} \mathrm{CFU} \mathrm{mL} \mathrm{m}^{-1}$, and probiotic culture count was higher than $1 \times 10^{6}$ CFU mL $\mathrm{m}^{-1}$, which guarantees their effect and capacity to survive in the digestive tract and spread in the intestine. The yogurt was stable during the 21 days of storage. Therefore, this study shows that goat milk yogurt is an adequate delivery vehicle of the probiotic culture L. casei and inulin.
\end{abstract}

Keywords: goat milk; yogurt; symbiotic; L. casei, inulin.

\section{Introduction}

Yogurt made from cow's milk is widely consumed in the world. On the other hand, there is a desire for alternatives to cow's milk due to problems relating to gastrointestinal intolerance and market demand for the formulation of novel dairy products. Goat's milk is reported to have higher digestibility and lower allergenic properties compared to cow's milk (Senaka Ranadheera et al., 2012). It also has a higher content of short chain fatty acids in milk fat, higher content of zinc, iron, and magnesium, and antibacterial characteristics (Slacanac et al., 2010). In addition, these benefits may be further enhanced by using goat's milk as a vehicle for delivering probiotics and prebiotics.

Probiotics have been defined as selective viable microorganisms that can be incorporated into foods offering positive impact on the health and nutrition to consumers. Lactobacilli are associated with maintaining optimum microbial balance in the digestive tract with well documented health benefits such as, strengthening the immune system, reduction of lactose intolerance, decrease of serum cholesterol level, and possible anti carcinogenic effects. Thus, these organisms have been extensively incorporated into dairy foods over the last years, and yogurts containing Lactobacillus are widely marketed (Senaka Ranadheera et al., 2012). Lactobacillus casei increases healthy immune system response and improves healthy cellular function and the growth of healthy bacteria in the intestinal tract. Some studies have shown that $L$. casei can modify potentially harmful bacterial activities such as those of b-glucuronidase and nitroreductase (Kayanush \& McGrew, 2007). Matsuzaki (2003) reviewed the biological activities of L. case $i$ that favorably influence human health. Bertazzoni
Minelli et al. (2004) examined four strains of $L$. casei for their potential use in new probiotic fermented milk based on their technological performances, in vitro adhesioncapacity, and intestinal transit tolerance after administration to rats. They reported that all four strains of $L$. casei are favorable for utilization in health-promoting foods.

Prebiotic substances, defined as non-digestible nutritional ingredients, affect the host in a positive way by selective stimulation of colon bacteria's growth and/or activity (Anadón et al., 2010). Inulin is one of them (Kip et al., 2006). This non-digestible carbohydrate is widely used in the food industry and is based on the nutritional and technological properties of inulin. It can be found in dairy products, in beverages, in low-fat foods, and in ice cream. At the same time, inuline has a bifidogenic effect, increasing calcium absorption with positive effects on bone health, lowering serum lipids promoting satiety with potential positive consequences for weight management (Parnell \& Reimer, 2009) and improving resistance to infections and stimulating the immune system (Lomax \& Calder, 2009).

The technological use of inulin is based on its properties as a sugar replacer, as a fat replacer, and texture modifier. Inulin seems particularly suitable as a fat replacer in low-fat dairy products since it may contribute to an improved mouthfeel. Guggisberg et al. (2009), Guven et al. (2005), Kip et al. (2006) and Paseephol et al. (2008) showed that inulin addition to lowfat yogurt resulted in enhanced creaminess. When inulin is added to food in low concentrations, the rheological properties and the sensory quality of the product will not be affected

Received 19 June, 2014

Accepted 29 Aug., 2014 (006409)

${ }^{1}$ Facultad de Ciencias de la Salud. Universidad Nacional de Salta - UNSA, Salta, Salta, Argentina, e-mail: ramon@unsa.edu.ar

${ }^{2}$ Facultad de Ciencias de la Salud. Universidad del Norte Santo Tomás de Aquino - UNSTA, Tucumán, Tucumán, Argentina

${ }^{*}$ Corresponding author 
strongly due to the neutral or slightly sweet taste and the limited effect on viscosity of this ingredient (Kalyani Nair et al., 2010). However, to make inulin based dietary fiber claims, inulin should be added in amounts that range from $1 \mathrm{~g} / 100 \mathrm{~mL}$ (Argentina, 1969), and contents of 3-8 g per portion have to be added to assure its beneficial effect (Meyer; Stasse-Wolthius, 2009). As inulin content increases, its effect on product structure and texture becomes important. At these higher levels, and due to its physicochemical properties, inulin can modify the texture of dairy products and may significantly influence their sensory quality (Meyer et al., 2011).

Symbiotics are the combined form of a probiotic and a prebiotics, which contribute to some properties of their formulation, including the fact that they enhance the survival of live bacteria in products resulting in an extension of useful life. They increase the number of the eaten bacteria that reach the colon in a viable way; they replace fat presenting synergy with many gelantin agents, and they stabilize emulsions and foams (Kip et al., 2006).

People lifestyles today lead to high consumption of high-fat foods and low fiber resulting in an increase in cholesterol levels, overweight, and high indexes of cardiovascular disease. All of this makes it necessary to decrease the intake of trans fat and saturated fat, decrease cholesterol levels, and to increase the intake of products that produce beneficial effects for human health (Taranto et al., 2008).

Therefore, the objective of the present study was to characterize Saanen goat milk, optimize the skimming process, and develop a potentially symbiotic yogurt (L. casei and inulin) by evaluating its chemical properties and acceptability and the viability of lactic acid bacteria and probiotic culture.

\section{Materials and methods}

\subsection{Chemical and microbiological characterization of goat milk}

The following parameters were determined in raw goat milk of Saanen breed (40 L): pH (pH meter Hanna), acidity by titration with $\mathrm{NaOH}$ N/9 (Dornic solution) in the presence of phenolphthalein indicator to $\mathrm{pH} 8.0$; carbohydrates, proteins, and fats using a milk analyzer (Lacto Star Funke Gerber), moisture, and total ash (Association of Official Analytical Chemists, 1998). The microbiological quality was evaluated by the methylene blue test (Association of Official Analytical Chemists, 1998); total aerobic mesophilic bacteria on Plate Count (International Commission on Microbiological Specifications for Foods, 1986); total coliforms on Violet Red Bile Lactose Agar (Mhone et al., 2011); and the somatic cell method by California Mastitis Test (CMT) using the Fossomatic electronic equipment. All determinations were performed in triplicate. Whole milk was skimmed according to the following parameters: heat treatment (raw, pasteurized at $63^{\circ} \mathrm{C}$ for $30 \mathrm{~min}$., and pasteurized at $72{ }^{\circ} \mathrm{C}$ for $1 \mathrm{~min}$ ); speed centrifugation using a refrigerated centrifuge Damon/IEC Division B-20a (8,800 and 9,800 rpm) and temperature ( 4 and $8{ }^{\circ} \mathrm{C}$ ). (Table 1) (Silveira et al., 1999).
Table 1. Combination of variables used during the standardization process of skimming.

\begin{tabular}{lcccc}
\hline Heat Treatment & $\begin{array}{c}8,800 \mathrm{rpm} \\
4{ }^{\circ} \mathrm{C}\end{array}$ & $\begin{array}{c}8,800 \mathrm{rpm} \\
8{ }^{\circ} \mathrm{C}\end{array}$ & $\begin{array}{c}9,800 \mathrm{rpm} \\
4{ }^{\circ} \mathrm{C}\end{array}$ & $\begin{array}{c}9,800 \mathrm{rpm} \\
8{ }^{\circ} \mathrm{C}\end{array}$ \\
\hline None (raw) & $\mathrm{A}$ & $\mathrm{D}$ & $\mathrm{G}$ & $\mathrm{J}$ \\
$63^{\circ} \mathrm{C} 30 \mathrm{~min}$. & $\mathrm{B}$ & $\mathrm{E}$ & $\mathrm{H}$ & $\mathrm{K}$ \\
$72^{\circ} \mathrm{C} 1$ min. & $\mathrm{C}$ & $\mathrm{F}$ & $\mathrm{I}$ & $\mathrm{L}$ \\
\hline
\end{tabular}

When choosing the appropriate method of skimming, it was taken into account that the fat content (by Gerber) (Association of Official Analytical Chemists, 1998) was not higher than $0.5 \mathrm{~g} / 100 \mathrm{~mL}$ of milk; and lipolysis was lower than $1.82 \mu \mathrm{eq}$ FFA (Free Fatty Acids)/mL of milk since higher values may result in unwanted tastes like stale, soapy, or bitter (Deeth, 2006). Chemical and microbiological characteristics of skim milk were determined according to the following procedures: total aerobic mesophilic bacteria in Plate Count Agar (International Commission on Microbiological Specifications for Foods, 1986); total coliforms on Violet Red Bile Lactose Agar (Mhone et al., 2011); moisture (Association of Official Analytical Chemists, 1998); carbohydrates by difference; protein determination (formol titration method) (Egan et al., 1991); fats by Gerber (Argentina, 1969); total ash; phosphorus, and calcium (Association of Official Analytical Chemists, 1998).

\subsection{Formulation of symbiotic yogurt}

Skim milk yogurt formulation was selected as a suitable method (mentioned above), which was incorporated with inulin powder Raftiline $\mathrm{HP}^{\circledR}$ (Orafti, São Pablo, Brasil) $\left(4.5 \mathrm{~g} \mathrm{~L}^{-1}\right)$, gelatin (INS 440) $\left(0.75 \mathrm{~g} \mathrm{~L}^{-1}\right)$, and sugar $\left(7.5 \mathrm{~g} \mathrm{~L}^{-1}\right)$. The culture starters Streptococcus salivarius subsp. thermophilus ST M6 ${ }^{\circledR}$ and Lactobacillus delbrueckii subsp. bulgaricus Lb- $12^{\circledR}$ were added at $0.04 \mathrm{~g} \mathrm{~L}^{-1}$ with bacilo/coco 1:1, and the probiotic culture: Lactobacillus casei subsp. rhamnoshus was added at three concentrations: 0.025 (Lc25); 0.010 (Lc10), and 0.005 (Lc05) $\mathrm{g} \mathrm{L}^{-1}$. The milk was fermented at $42 \pm 1{ }^{\circ} \mathrm{C}$ for 2 hours, up to $\mathrm{pH}$ 4.6. The product was then gently shaken and refrigerated at $4 \pm 2{ }^{\circ} \mathrm{C}$.

The count of $L$. case $i$ was performed on MRS vancomycin agar. The MRS broth was prepared with about $2 \mathrm{~mL}$ of $0.05 \mathrm{~g}$ vancomycin/100 $\mathrm{mL}$. The solution was then added to $1000 \mathrm{~mL}$ of MRS broth to obtain 1mg/L final concentration. Agar was added at a concentration of $12 \mathrm{~g} / \mathrm{L}$. Final $\mathrm{pH}$ was 5.60. The yogurt in the cup was briefly agitated using a sterile pipette, and $1 \mathrm{~g}$ yogurt was taken from the center of the yogurt cup and transferred to a sterile bottle containing $99 \mathrm{~mL}$ of sterile peptone water. The contents were agitated with previously prepared 10 serial dilutions. Plate counts were determined by plating serial dilutions of yogurt on MRS vancomycin agar. The plates were incubated anaerobically at $37^{\circ} \mathrm{C}$ for $72 \mathrm{~h}$. White, shiny, smooth colonies of $1.0 \mathrm{~mm}$ in diameter were counted.

\subsection{Sensory analyses}

Sensory evaluation was performed with 100 untrained panelists aged from 20 to 25 years old. The individuals were regular consumers of yogurt, not allergic to milk, and willing to 
participate. The yogurt samples were evaluated for consistency, aroma, and overall flavor using a structured 9-point hedonic scale ranging from 1 (Dislike it very much) to 9 (Liked it very much), according to the Institute of Food Technologists (2007, Part II). Each sample (15g) was coded with a 3-digit random number and served in $50 \mathrm{~mL}$ disposable transparent plastic cups. The yogurt samples were evaluated after 1 day of refrigerated storage at $4{ }^{\circ} \mathrm{C}$.

\subsection{Chemical characterization and viability of lactic acid bacteria and probiotic culture}

The final product was tested for: moisture, carbohydrates, and total dietary fiber by enzymatic-gravimetric activity (Association of Official Analytical Chemists, 1998); inulin by HPLC (Zuleta \& Sambucetti, 2001); proteins by the Kjeldhal method; fats by alkaline hydrolysis; ashes by incineration with the furnace at $550^{\circ} \mathrm{C}$, calcium by atom absorption spectrometry, and phosphorus by molecular absorption spectrometry (Association of Official Analytical Chemists, 1998).

The yogurt was evaluated for 21 days during storage at $4 \pm 1^{\circ} \mathrm{C}$, and every 7 days the $\mathrm{pH}$, Dornic acidity, and percentage of draining by weight difference was determined. The $\mathrm{pH}$ values of the yogurt samples were measured using a $\mathrm{pH}$ meter (Hanna) after calibration with fresh $\mathrm{pH} 4.0$ and 7.0 standard buffers. Titratable acidity (TA) was determined after mixing the yogurt sample with $10 \mathrm{~mL}$ of hot distilled water and titrating with $0.1 \mathrm{~N} \mathrm{NaOH}$ using $0.5 \%$ phenolphthalein indicator (Dave \& Shah, 1997).

\subsection{Statistical analysis}

To select the temperature and the revolutions per minute in which the milk got skimmed, the samples were analyzed by ANOVA and Duncan tests determining the significance level between them. The results were expressed as mean \pm standard deviation (SD). After verification of a normal distribution of data, ANOVA and Duncan tests were used. Differences were considered significant at $P<0.05$.

\section{Results and discussion}

\subsection{Chemical and microbiological characterization of goat milk}

The physicochemical and microbiological composition of raw goat milk is shown in Table 2. The low acidity levels may be due to the fact that acidity is influenced by casein, mineral salts, and ions found according to the period of lactation. The $\mathrm{pH}$ value was 6.7 , and it depends mainly on caseins' stability. It is affected by the lactation phase, diet, goat's breed, bubbles of carbonic gas given off during milking, and refrigeration or transportation of the milk (Albenzio \& Santillo, 2011). Values of protein and fat were similar to those reported in the literature. The first nutrient may be influenced by breastfeeding and race (Albenzio \& Santillo, 2011), and the second, in addition to these reasons, it is also influenced by the animals' diet. (Park et al., 2007). The methylene blue test showed that the milk had a good hygienic quality, with less than 100,000 bacteria/mL.
The count of total aerobic mesophilic and coliform bacteria established by Argentina Legislation for milk from the same dairy farm is $3.3 \times 10^{7} \mathrm{CFU} / \mathrm{mL}$ (Argentina, 1969). Both tests showed that the milk produced by the farm had good hygienic quality. The milk had no signs of mastitis, intramammary infections, and fecal contamination during milking and/or inadequate hygiene due to use of the milking machine (Kondyli et al., 2012). The somatic cell count in the milk was lower than the maximum level established by Argentina Legislation: 400,000 cells/mL (Argentina, 1969). Generally, the results in Table 2 show that levels of microbial contamination of raw goat milk are satisfactory (Kondyli et al., 2012). Table 3 shows the values of fat and lipolysis of goat milk with and without heat treatment, subjected to different spin speed and temperatures, which were used to select the best skimming process.

The fat content ranged from $0.00(\mathrm{~A}, \mathrm{D}, \mathrm{K}, \mathrm{L})$ to 0.22 (I) $\mathrm{g} / 100 \mathrm{~mL}$, and none of the values were higher to $0.5 \mathrm{~g} / 100 \mathrm{~mL}$ (Argentina, 1969; Güler \& Gürsoy-Balc, 2011). No statistically significant differences between the samples $(P \leq 0.05)$ were found.

Lipolysis values ranged from $1.15(\mathrm{~K})$ to $5.45(\mathrm{G}) \mu \mathrm{eq}$ $\mathrm{FFA} / \mathrm{mL}$; the last value with a high FFA level would be unacceptable to most people due to the changes in the flavor

Table 2. Chemical composition and microbiological quality of whole raw goat milk.

\begin{tabular}{cc}
\hline & Whole Raw Goat Milk $(100 \mathrm{~mL})$ \\
\hline $\mathrm{pH}$ & 6.7 \\
Acidez & $10.50 \pm 0.51{ }^{\circ} \mathrm{D}$ \\
Moisture $(\mathrm{g})$ & $87.50 \pm 0.70$ \\
Carbohydrates $(\mathrm{g})$ & $5.01 \pm 0.00$ \\
Proteins $(\mathrm{g})$ & $2.90 \pm 0.00$ \\
Fats $(\mathrm{g})$ & $3.56 \pm 0.00$ \\
Ash $(\mathrm{g})$ & $1.03 \pm 0.00$ \\
Methylene Blue & No change in color for 5.5 hours \\
Aerobic Mesophilic & $2.6 \times 10^{7} \mathrm{CFU} / \mathrm{mL}$ \\
Total Coliforms & $2.5 \times 10^{4} \mathrm{CFU} / \mathrm{mL}$ \\
Somatic Cells & $331,000 \mathrm{cell} / \mathrm{mL}$
\end{tabular}

Means \pm standard deviation ( $n=3)$. mL: milliliter; g: grams; CFU/mL: Colony Forming Units/ mL.

Table 3. Fat content $(\mathrm{g} / 100 \mathrm{~mL}$ ) and lipolysis ( $\mu$ eq of Free Fatty Acids/ $\mathrm{mL}$ ) of skimmed milk.

\begin{tabular}{ccc}
\hline Heat Treatment & Fat $(\mathrm{g} \%)$ & FFA $(\mu \mathrm{eq} / \mathrm{mL})$ \\
\hline A & $0.00 \pm 0.00^{\mathrm{g}}$ & $1.41 \pm 0.04^{\mathrm{e}}$ \\
B & $0.05 \pm 0.07^{\mathrm{g}}$ & $1.81 \pm 0.10^{\mathrm{bc}}$ \\
C & $0.10 \pm 0.00^{\mathrm{g}}$ & $1.67 \pm 0.09^{\mathrm{cd}}$ \\
D & $0.00 \pm 0.00^{\mathrm{g}}$ & $1.92 \pm 0.04^{\mathrm{b}}$ \\
E & $0.15 \pm 0.07^{\mathrm{g}}$ & $1.99 \pm 0.04^{\mathrm{b}}$ \\
F & $0.15 \pm 0.07^{\mathrm{g}}$ & $1.54 \pm 0.09^{\mathrm{de}}$ \\
G & $0.05 \pm 0.07^{\mathrm{g}}$ & $5.45 \pm 0.09^{\mathrm{a}}$ \\
H & $0.15 \pm 0.07^{\mathrm{g}}$ & $1.34 \pm 0.04^{\mathrm{ef}}$ \\
I & $0.22 \pm 0.03^{\mathrm{g}}$ & $1.54 \pm 0.00^{\mathrm{de}}$ \\
J & $0.05 \pm 0.07^{\mathrm{g}}$ & $1.94 \pm 0.04^{\mathrm{b}}$ \\
K & $0.00 \pm 0.00^{\mathrm{g}}$ & $1.15 \pm 0.14^{\mathrm{f}}$ \\
L & $0.00 \pm 0.00^{\mathrm{g}}$ & $1.65 \pm 0.02^{\mathrm{cd}}$ \\
\hline
\end{tabular}

Means \pm standard deviation $(n=3)$. Means in the same row with different letters are significantly different $(P<0.05)$. g: grams; mL: milliliter; FFA: Free Fatty Acids; $\mu$ eq: milliequivalents; min.: minutes. 
which would described as rancid, butyric, astringent and even bitter. It is possible that such situation did not occur with the other samples without thermal treatment. In the samples with thermal treatment, the lipolysis could have happened before pasteurization since this mechanism activates lipases (Deeth, 2006).

It was observed that the samples that were not heat-treated, showed values of lipolysis of $1.92(\mathrm{D}), 5.45(\mathrm{G})$, and $1.94(\mathrm{~J}) \mu \mathrm{eq}$ $\mathrm{FFA} / \mathrm{mL}$. On the other hand, the milk that was pasteurized at $63^{\circ} \mathrm{C}$ for 30 minutes had a value of 1.99 (E) $\mu$ eq FFA $/ \mathrm{mL}$, which is higher than the reference value (Argentina, 1969), and 1.81 (B) $\mu$ eq $\mathrm{FFA} / \mathrm{mL}$, which is close to the maximum acceptable limit; therefore, these samples were not considered.

The presence of total free fatty acids in the raw samples (A, D, G, J) could be due to the action of lipases in milk, which are inactivated only by heat treatment (Chilliard et al., 2003).

There were difficulties in the separation of fat after the processing of the milk samples that were centrifuged at $8{ }^{\circ} \mathrm{C}(\mathrm{D}$, $\mathrm{E}, \mathrm{F}$ and $\mathrm{J}, \mathrm{K}, \mathrm{L}$, and for that reason, they were not considered appropriate.

The selected process for the skimmed of the goat milk was that was heat-treated at $63{ }^{\circ} \mathrm{C}$, centrifuged at 9,800 rpm at the temperature of $4{ }^{\circ} \mathrm{C}$ for 15 minutes $(\mathrm{H})$, in which the lipolysis value was lower (1.34 eq of FFA $/ \mathrm{mL}$ milk) and fat separation was feasible. The results of chemical composition and microbiological characterization of goat milk is shown in Table 4.

Macronutrient content was similar to the reference values. The count of total aerobic mesophilic and coliform bacteria was $9 \times 10^{2} \mathrm{CFU} / \mathrm{mL}$ and $0 \mathrm{CFU} / \mathrm{mL}$, respectively, values that are lower than the maximum allowed by Argentina Legislation $\left(9 \times 10^{2} \mathrm{CFU} / \mathrm{mL}\right.$ and $\left.0 \mathrm{CFU} / \mathrm{mL}\right)$. These results indicate the good sanitary and hygienic quality of the milk (Kondyli et al., 2012) (Table 4).

\subsection{Formulation of symbiotic yogurt}

The non-fat yogurt is sensitive to mechanical defects since it has fewer dry substances. To stabilize consistency and to prevent syneresis in yogurt, a stabilizer of a hydrocolloid type (gelatin) was added (Spreer, 1991); inulin, which affects viscosity in a positive way, was also added in order to achieve high water retention capacity through hydrogen bonding with the yogurt proteins contributing to the formation of gel. A stable product was obtained at the temperature of $38 \pm 1{ }^{\circ} \mathrm{C}$, which resulted in yogurt with pH 4.5 (Martín-Diana et al., 2003) and a whipped consistency. The viability of lactic acid bacteria and probiotic culture is shown in Table 5.

The count of lactic bacteria ranged between $6 \times 10^{7}$ and $9 \times 10^{7} \mathrm{CFU} \mathrm{mL} \mathrm{m}^{-1}$, values that are within those established by Argentina Legislation $\left(10^{7} \mathrm{CFU} \mathrm{mL}^{-1}\right)$ (Argentina, 1969)

With respect to the probiotic culture count of sample Lc25 was the only one that was between $10^{6}$ to $10^{9} \mathrm{CFU} \mathrm{mL}^{-1}$, which guarantees its effectiveness and capacity to survive the digestive tract and spread in the intestine (Taranto et al., 2008; ManiLópez et al., 2014).

Sample Lc25 had the largest probiotic culture count $\left(3 \times 10^{7} \mathrm{CFU} \mathrm{mL}{ }^{-1}\right)$, which ensures its effect and ability to survive the digestive tract and proliferate in the intestine (Taranto et al., 2008; Mani-López et al., 2014); therefore, this product was selected for further testing.

The values obtained were higher than those found by Salva et al. (2007), who obtained probiotic culture count of $1.6 \times$ $10^{6} \mathrm{CFU} \mathrm{mL} \mathrm{m}^{-1}$ in fermented goat milk, which shows the survival of L. casei in acidic medium.

\subsection{Sensory analysis}

Table 6 shows the results (\%) of the acceptability test of potentially symbiotic non-fat yogurt The highest percentage obtained (35\%) corresponds to the score 8 on the hedonic scale ("Like it"); the average score was $7.62 \pm 1.24$ : $95 \%$ of the reviewers liked the product, $2 \%$ showed indifference, and the $3 \%$ remaining disliked it.

Table 4. Chemical composition and microbiological quality of pasteurized skimmed goat milk (Sample H).

\begin{tabular}{cc}
\hline & $\begin{array}{c}\text { Pasteurized Skimmed Goat Milk } \\
(100 \mathrm{~mL})\end{array}$ \\
\hline Moisture (g) & $91.97 \pm 0.35$ \\
Carbohydrates (g) & $4.39 \pm 0.00$ \\
Proteins (g) & $2.63 \pm 0.00$ \\
Fats (g) & $0.10 \pm 0.00$ \\
Ash (g) & $0.91 \pm 0.11$ \\
Calcium (mg) & $163.57 \pm 3.95$ \\
Phosphorus (mg) & $108.26 \pm 10.48$ \\
Aerobic Mesophilic & $9 \times 10^{2} \mathrm{CFU} \mathrm{mL}^{-1}$ \\
Total Coliforms & $0 \mathrm{CFU} \mathrm{\textrm {mL } ^ { - 1 }}$ \\
\hline
\end{tabular}

Means \pm standard deviation $(n=3)$. mL: milliliter.

Table 5. Viability of lactic acid bacteria and probiotic culture of a potentially symbiotic non-fat yogurt.

\begin{tabular}{ccc}
\hline Samples & $\begin{array}{c}\text { Lactic bacteria } \\
\text { CFU mL }\end{array}$ & $\begin{array}{r}\text { Probiotic culture } \\
\text { CFU mL } \mathrm{mL}^{-1}\end{array}$ \\
\hline Lc25 & $9 \times 10^{7}$ & $3 \times 10^{7}$ \\
Lc10 & $6 \times 10^{7}$ & $8 \times 10^{5}$ \\
Lc05 & $6 \times 10^{7}$ & $2.5 \times 10^{4}$ \\
\hline
\end{tabular}

Table 6. Percentage of acceptability of potentially symbiotic non-fat yogurt.

\begin{tabular}{ccc}
\hline Hedonic scale Points & Acceptability & Percentage (\%) \\
\hline 9 & Liked it very much & 25 \\
8 & Liked it & 35 \\
7 & Liked it regularly & 27 \\
6 & Liked it little & 8 \\
5 & Indifferent & 2 \\
4 & Disliked it slightly & 1 \\
3 & Disliked it regularly & 2 \\
2 & Disliked it a lot & 0 \\
1 & Disliked it very much & 0 \\
& Total & 100 \\
& Average score & $7.62 \pm 1.24$ \\
\hline
\end{tabular}


The consumer panel evaluated the samples for consistency, aroma and overall flavor. As for the taste, $72 \%$ of the panelists found it pleasant, 23\% considered it acid, and 5\% disliked it; $97 \%$ of the consumers considered the acidic taste as nice, and $94 \%$ considered consistency as adequate.

\subsection{Chemical characterization and feasibility of starters and probiotic bacteria}

Table 7 shows the physicochemical characteristics of potentially symbiotic non-fat yogurt. Moisture values and carbohydrates were similar to those observed by Quintana \& Ramón (2007) (77.90 and $11.17 \mathrm{~g} / 100 \mathrm{~mL}$, respectively) in a fermented goat milk containing probiotic culture.

The inulin content was $2.15 \mathrm{~g} / 100 \mathrm{~mL}$; a $48 \%$ loss was observed compared to the initial content, which may be due to the fact that it is hydrolyzed into shorter chains and fructose, according to the conditions of temperature, acidity, time, and water activity (Coussement, 2010). A large peak in the chromatogram showed that inulin was hidrolyzed to fructose (Zuleta \& Sambucetti, 2001). Moreover, inulin may have served as a substrate for maintaining the viability of $\mathrm{L}$. casei Protein content was lower than the reference values, which could be due to its lower content in the goat milk evaluated. Fat content confirms that it is a nonfat product. The $\mathrm{Ca} / \mathrm{P}$ ratio was 1.2:1. The recommended value is equal to or greater than 1 , and when it is less than that, it becomes a triggering factor for bone loss (Teegarden et al., 1998) (Table 7).

The $\mathrm{pH}$ on day 1 was 4.5 , but it decreased to 4.4 on day 7 . This value was kept stable until day 21 ; this may be due to the fact that lactic bacteria stabilized between days 10 and 15 of storage (Minervini et al., 2009).

Dornic acidity was between 73 and $76^{\circ} \mathrm{D}$ during the 21 days of storage, and it is within the range established by Argentina Legislation $\left(60-150^{\circ} \mathrm{D}\right)$ (Argentina, 1969).

The percentage of draining ranged between 0.00 and $0.38 \%$. Yogurts made with inulin in general, do not exhibit syneresis during 21 days of refrigerated storage $\left(4 \pm 1{ }^{\circ} \mathrm{C}\right)$, because of the water retention capacity of this polysaccharide. This phenomenon is of great importance because the presence of exudate can cause consumer rejection (Minervini et al., 2009).

Table 7. Chemical composition of symbiotic non-fat yogurt made from goat milk.

\begin{tabular}{cc}
\hline & Symbiotic Yogurt $(100 \mathrm{~mL})$ \\
\hline Moisture $(\mathrm{g})$ & $79.23 \pm 0.05$ \\
Carbohydrates $(\mathrm{g})$ & $12.67 \pm 0.00$ \\
Total Dietary Fiber $(\mathrm{g})$ & $3.04 \pm 0.00$ \\
Inulin $(\mathrm{g})$ & $2.15 \pm 0.00$ \\
Proteins $(\mathrm{g})$ & $4.04 \pm 0.00$ \\
Fats $(\mathrm{g})$ & $0.04 \pm 0.00$ \\
Ash (g) & $0.98 \pm 0.00$ \\
Calcium (mg) & $114.80 \pm 4.71$ \\
Phosphorus (mg) & $94.20 \pm 8.29$ \\
Total Calories & $66 \mathrm{kcal}$ \\
\hline
\end{tabular}

Means \pm standard deviation $(n=3)$. mL: milliliter; g: grams; mg: milligrams; kcal: kilocalories.
A study on the useful life and acceptability of a probiotic yogurt shows that it is does not undergo changes after 38 days of storage at $10^{\circ} \mathrm{C}$; thus, the sensory characteristics of the products are not modified (Minervini et al., 2009). If the product is kept refrigerated and with a $\mathrm{pH}$ no lesser than 4.2 , the residual activity of the probiotic culture will be minimal, and its survival will be optimized. It is worth mentioning that a count higher than $10^{7} \mathrm{CFU} / \mathrm{mL}$ will guarantee an adequate number of viable cells during the useful life of the product

\section{Conclusions}

The goat milk used showed good chemical and microbiological quality. The appropriate process conditions to obtain skim milk with a low level of lipolysis were: pasteurization at $63{ }^{\circ} \mathrm{C}$ for 30 minutes and centrifugation at $9,800 \mathrm{rpm}$ at a temperature of $4{ }^{\circ} \mathrm{C}$ for 15 minutes. In addition, the temperature facilitated separation of fat.

Overall, this research shows the technological potential and adequacy of using goat milk to produce potentially symbiotic yogurt with good nutritional value with respect to protein, $\mathrm{Ca} / \mathrm{P}$, good sensory score and acceptability (95\%) with good viability of lactic acid bacteria and probiotic culture. No flavors were associated to the goat milk, and satisfactory probiotic viability was maintained throughout the 21 days of refrigerated storage.

\section{Acknowledgements}

The authors wish to thank Professor Mark Shaw for his invaluable help with language revision. The authors are also grateful to Dr. Mónica Chávez and the Instituto Nacional de Tecnología Agropecuaria (INTA - Cerrillos) for providing the goat milk and for the use of the milk analyzer Lacto Star Funke Gerber.

\section{References}

Albenzio, M., \& Santillo, A. (2011). Biochemical characteristics of ewe and goat milk: effect on the quality of dairy products. Small Ruminant Research, 101(1-3), 33-40. Retrieved from http://www. sciencedirect.com/science/article/pii/S0921448811003725 http:// dx.doi.org/10.1016/j.smallrumres.2011.09.023

Anadón, A., Martínez-Larrañaga, M. R., Caballero, V., \& Castellano, V. (2010). Assessment of prebiotics and probiotics: an overview. In R. Watson \& V. R. Preedy (Eds.), Bioactive foods in promoting health: probiotics and prebiotics (cap. 2, pp. 19-41). Boston: Academic Press. Retrieved from http://www.sciencedirect.com/science/article/pii/ B9780123749383000025

Argentina, Ministerio de Salud, Administración Nacional de Medicamentos, Alimentos, y Tecnología Médica - ANMAT. (1969). Declárase vigente en todo el territorio de la República, con la denominación de Código Alimentario Argentino (Ley 18.284). Boletin Oficial de la Republica Argentina. Retrieved from http:// www.anmat.gov.ar/alimentos/normativas_alimentos_caa.asp

Association of Official Analytical Chemists - AOAC. (1998). Official methods of analysis (16th ed.). Arlington.

Bertazzoni Minelli, E., Benini, A., Marzotto, M., Sbarbati, A., Ruzzenente, O., Ferrario, R., Hendriks, H., \& Dellaglio, F. (2004). Assessment of novel probiotic Lactobacillus casei strains for the production of functional dairy foods. International Dairy Journal, 
14(8), 723-736. Retrieved from http://www.sciencedirect.com/ science/article/pii/S0958694604000202 http://dx.doi.org/10.1016/j. idairyj.2004.01.007

Chilliard, Y., Ferlay, A., Rouel, J., \& Lambert, G. (2003). A review of nutritional and physiological factors affecting goat milk lipid synthesis and lipolysis. Journal Dairy Science, 86(5), 1752-1770. Retrieved from http://www.sciencedirect.com/science/article/ pii/S0022030203737618 http://dx.doi.org/10.3168/jds.S00220302(03)73761-8

Coussement, P. (2010). Acid and thermal stability: application file. Belgium: Orafti Active Food Ingredients.

Dave, R. I., \& Shah, N. P. Viability of yoghurt and probiotic bacteria in yoghurts made from commercial starter cultures. International Dairy Journal, 7(1), 31-41, 1997. Retrieved from http://www. sciencedirect.com/science/article/pii/S09586946960004655 http:// dx.doi.org/10.1016/S0958-6946(96)00046-5

Deeth, H. C. (2006). Lipoprotein lipase and lipolysis in milk. International Dairy Journal, 16(6), 555-562. Retrieved from http:// www.sciencedirect.com/science/article/pii/S0958694605002591 http://dx.doi.org/10.1016/j.idairyj.2005.08.011

Egan H., Kirk, R., \& Sawyer, R. (1991). Pearson's composition and analysis of foods (8th ed.). London: Longman.

Guggisberg, D., Cuthbert-Steven, J., Piccinali, P., Bütikofer, U., \& Eberhard, P. (2009). Rheological, microstructural and sensory characterization of low-fat and whole milk set yogurt as influenced by inulin addition. International Dairy Journal, 19(2), 107-115. Retrieved from http://www.sciencedirect.com/science/article/pii/ S0958694608001386 http://dx.doi.org/10.1016/j.idairyj.2008.07.009

Güler, Z., \& Gürsoy-Balc, A. C. (2011). Evaluation of volatile compounds and free fatty acids in set types yogurts made of ewes', goats' milk and their mixture using two different commercial starter cultures during refrigerated storage. Food Chemistry, 127(3), 1065-1071. Retrieved from http://www.sciencedirect.com/ science/article/pii/S0308814611001944 http://dx.doi.org/10.1016/j. foodchem.2011.01.090

Guven, M., Yasar, K., Karaca, O. B., \& Hayaloglu, A. A. (2005). The effect of inulin as a fat replacer on the quality of set-type low-fat yogurt manufacture. International Journal of Dairy Technology, 58(3), 180-184. Retrieved from http://onlinelibrary.wiley.com/ enhanced/doi/10.1111/j.14710307.2005.00210.x/?isReportingDone =true http://dx.doi.org/10.1111/j.1471-0307.2005.00210.x

Institute of Food Technologists - IFT. (2007). Sensory Science 101. Part II: sensory evaluation methods. Chicago.

International Commission on Microbiological Specifications for Foods - ICMSF. (1986). Microorganisms in foods 2: sampling for microbiological analysis: principles and specific applications (2nd ed.). Toronto: University of Toronto.

Kalyani Nair, K., Kharb, S., \& Thompkinson, D. K. (2010). Inulin dietary fiber with functional and health atributes: a review. Food Reviews International, 26(2), 189-203. http://dx.doi. org/10.1080/87559121003590664

Kayanush, J. A., \& McGrew, P. (2007). Quality attributes of yogurt with Lactobacillus casei and various prebiotics. $L W T$ - Food Science and Technology, 40(10), 808-1814. Retrieved from http://www. sciencedirect.com/science/article/pii/S0023643807000424

Kip, P., Meyer, D., \& Jellena, R. H. (2006). Inulins improve sensoric and textural properties of low-fat yogurts. International Dairy Journal, 16(9), 1098-1103. Retrieved from http://www.sciencedirect.com/ science/article/pii/S0958694605002414 http://dx.doi.org/10.1016/j. idairyj.2005.10.011
Kondyli, E., Svarnas, C., Samelis, J., \& Katsiari, M. C. (2012). Chemical composition and microbiological quality of ewe and goat milk of native Greek breeds. Small Romiant Research, 103(2-3), 194199. Retrieved from http://www.sciencedirect.com/science/ article/pii/S0921448811003932 http://dx.doi.org/10.1016/j. smallrumres.2011.09.043

Lomax, A. R., \& Calder, P. C. (2009). Prebiotics, immune function, infection and inflammation: a review of the evidence. British Journal of Nutrition, 101(5), 633-658. Retrieved from http:// www.nutrociencia.com.br/upload_files/artigos_download/ rewiew_prebioticos.pdf PMid:18814803. http://dx.doi.org/10.1017/ S0007114508055608

Mani-López, E., Palou, E., \& López-Malo, A. (2014). Probiotic viability and storage stability of yogurts and fermented milks prepared with several mixtures of lactic acid bacteria. Journal od Dairy Science, 97(5), 2578-2590. Retrieved from http://www.sciencedirect.com/ science/article/pii/S0022030214002549 PMid:24745665. http:// dx.doi.org/10.3168/jds.2013-7551

Martín-Diana, A. B., Janer, C., Peláez, C., \& Requena, T. (2003). Development of a fermented goat's milk containing probiotic bacteria. International Dairy Journal, 13(10), 827-833. Retrieved from http:// www.sciencedirect.com/science/article/pii/S0958694603001171 http://dx.doi.org/10.1016/S0958-6946(03)00117-1

Matsuzaki, T. (2003). Health properties of milk fermented with Lactobacillus casei strain Shirota (LcS). In E. R. Farnworth (Ed.), Handbook of fermented functional foods (cap. 6, pp. 145-175). Boca Raton: CRC Press. Retrieved from http://www.crcnetbase.com/doi/ abs/10.1201/9780203009727.ch6

Meyer, D., Bayarri, S., Tárrega, A., \& Costell, E. (2011). Inulin as texture modifier in dairy products. Food Hydrocolloids, 25(8), 1881-1890. Retrieved from http://www.sciencedirect.com/science/ article/pii/S0268005X1100124X http://dx.doi.org/10.1016/j. foodhyd.2011.04.012

Meyer, D., \& Stasse-Wolthuis, M. (2009). The bifidogenic effect of inulin and oligofructose and its consequences for gut health. European Journal of Clinical Nutrition, 63, 1277-1289. Retrieved from http:// www.nature.com/ejcn/journal/v63/n11/full/ejcn200964a.html PMid:19690573. http://dx.doi.org/10.1038/ejcn.2009.64

Mhone, T. A., Matope, G., \& Saidi, P. T. (2011). Aerobic bacterial, coliform, Escherichia coli and Staphylococcus aureus counts of raw and processed milk from selected smallholder dairy farms of Zimbabwe. International Journal of Food Microbiology, 151(2), 223-228. Retrieved from http://www.sciencedirect.com/science/ article/pii/S0168160511005162 PMid:21944662. http://dx.doi. org/10.1016/j.ijfoodmicro.2011.08.028

Minervini, F., Bilancia, M. T., Siragusa, S., Gobbetti, M., \& Caponio, F. (2009). Fermented goats' milk produced with selected multiple starters as a potentially functional food. Food Microbiology, 26(6), 559-564. Retrieved from http://www.sciencedirect.com/science/ article/pii/S0740002009000641 PMid:19527829. http://dx.doi. org/10.1016/j.fm.2009.03.008

Park, Y. W., Juárez, M., Ramos, M., \& Haenlein, G. F. W. (2007). Physico-chemical characteristics of goat and sheep milk. Small Ruminant Research, 68(1-2), 88-113. Retrieved from http://www. sciencedirect.com/science/article/pii/S0921448806002549 http:// dx.doi.org/10.1016/j.smallrumres.2006.09.013

Parnell, J. U., \& Reimer, R. A. (2009). Weight loss during oligofructose supplementation is associated with decreased ghrelin and increased peptide YY in overweight and obese adults. American Journal of Clinical Nutrition, 89(6), 1751-1759. Retrieved from http:// 
ajcn.nutrition.org/content/89/6/1751.full.pdf PMid:19386741 PMCid:PMC3827013. http://dx.doi.org/10.3945/ajcn.2009.27465

Paseephol, T., Small, D. M., \& Sherkat, F. (2008). Rheology and texture of set yogurt as affected by inulin addition. Journal of Texture Studies, 39(6), 617-634. Retrieved from http://onlinelibrary.wiley. com/doi/10.1111/j.1745-4603.2008.00161.x/full http://dx.doi. org/10.1111/j.1745-4603.2008.00161.x

Quintana, A. V., \& Ramón, A. N. (2007). Formulación de un producto fermentado prebiótico a partir de leche de cabra. Tecnología Láctea Latinoamericana, 4, 44-50.

Salva, S., Kairuz, M., Haro, C., Agüero, G., Rabasa, A., \& Alvarez, S. (2007). Desarrollo de una leche caprina fermentada probiótica: su efecto en la recuperación de ratones desnutridos. Argentina: Sitio Argentino de Producción Animal. Retrieved from http://www. produccion-animal.com.ar/produccion_caprina/leche_caprina/88salva.pdf

Senaka Ranadheera, C., Evans, C. A., Adams, M. C., \& Baines, S. K. (2012). Probiotic viability and physico-chemical and sensory properties of plain and stirred fruit yogurts made from goat's milk. Food Chemistry, 135(3), 1411-1418. Retrieved from http:// www.sciencedirect.com/science/article/pii/S0308814612009971 PMid:22953874. http://dx.doi.org/10.1016/j.foodchem.2012.06.025
Silveira, I. A., Carvalho, E. P., Teixeira, D., \& Barrios, B. E. B. (1999). Verificación de las actividades proteolíticas y lipolíticas de la flora microbiana aislada de la leche cruda tipo B refrigerada. II. Microorganismos psicrotróficos. Revista Latinoamericana de Microbiología, 41(2), 85-89. PMid:10932755.

Slacanac, V., Bozanic, R., Hardi, J., Rezessyne Szabo, J., Lucan, M., \& Krstanovic, V. (2010). Nutritional and therapeutic value of fermented caprine milk. International Journal of Dairy Technology, 63(2), 171-189. Retrieved from https://bib.irb.hr/ datoteka/451883.2010_Int_J_of_Dairy_Technol_KOZA.pdfhttp:// dx.doi.org/10.1111/j.1471-0307.2010.00575.x

Spreer, E. (1991). Lactología industrial. Zaragoza: Acribia.

Taranto, M. P., Médici, M., \& Font de Valdez, G. (2008). Socios para la salud. Énfasis Alimentación, 26(6), 74-80.

Teegarden, D., Lyle, R. M., McCabe, G. P., McCabe, L. D., Proulx, W. R., Michon, K., Knight, A. P., Conrad Johnston, C., \& Weaver, C. M. (1998). Dietary calcium, protein, and phosphorus are related to bone mineral density and content in young women. American Journal of Clinical Nutrition, 68(3), 749-754. Retrieved from http:// ajcn.nutrition.org/content/68/3/749.full.pdf+html PMid:9734757.

Zuleta, A., \& Sambucetti, M. E. (2001). Inulin determination for food labeling. Journal Agricultural and Food Chemistry, 49(10), 45704572. http://dx.doi.org/10.1021/jf010505o 